\title{
Growth Action of Land Utilization Pattern in Parbhani District of Maharashtra, India
}

\author{
A.A. Awchar ${ }^{1}$, K.V. Deshmukh ${ }^{2}$ and R.D. Shelke ${ }^{1 *}$ \\ ${ }^{1}$ Department of Agricultural Economics, College of Agriculture, Latur, \\ Vasantrao Naik Marathwada Krishi Vidyapeeth, Parbhani, India \\ ${ }^{2}$ College of Agriculture, Ambajogai, Vasantrao Naik Marathwada Krishi Vidyapeeth, \\ Parbhani, Inida \\ *Corresponding author
}

\section{A B S T R A C T}

\begin{tabular}{|c|}
\hline Keywords \\
\hline $\begin{array}{l}\text { Growth action, } \\
\text { Land utilization } \\
\text { pattern, Gross } \\
\text { cropped area, Waste } \\
\text { land }\end{array}$ \\
\hline Article Info \\
\hline $\begin{array}{l}\text { Accepted: } \\
15 \text { April } 2019 \\
\text { Available Online: } \\
10 \text { May } 2019\end{array}$ \\
\hline
\end{tabular}

\section{Introduction}

Land is an important resource because it covers about $30 \%$ of the total area of the earth's surface and not all parts of this small percentage are habitable or productive. The pattern of land use of country at any particular time is determined by the physical, economic and institutional framework taken together. Though technological progress in agriculture and agricultural intensification have mitigated the demand for land for non-agricultural purposes are posing a serious challenge to both researchers and policy makers. Intensive agriculture coupled with large-scale irrigation projects without utilized or unutilized. For sustainable utilization of the land ecosystems, it is essential to know the natural characteristics, extent and location, its quality, productivity, suitability and limitations of various land uses. The growth of population is greater than the rate of growth of food production. It is usually achieved through proper use of land resources with the application of bio-fertilizers, double cropping, modern methods of irrigation and manpower.

In developing countries, the agriculture is the backbone of the economy. In India, agriculture contributes $17-18$ per cent to the 
Gross Domestic Product (GDP) during the year 2017-18. Agriculture sector provides employment to more than 50 per cent of country's workforce and is the single largest private sector occupation. The government has already taken steps to address two major factors (soil and water) critical to improve agriculture production. Steps have been taken to improve soil fertility on a sustainable basis through the soil health card scheme and to support the organic farming scheme 'Paramparagat Krishi Vikas Yojana'. Other steps include improved access to irrigation through 'Pradhanmantri Krishi Sinchai Yojana'; enhanced water efficiency through 'Per Drop More Crop'; continued support to Pradhan Mantari Fasal Bima Yojana and the creation of a unified national agriculture market to boost the incomes of farmers.

In Parbhani, Net sown area, gross cropped area, land under non-agriculture use shows increase in percentage change with positive sign. Area under forest, permanent pastures, area sown more than once gross cropped, cultivable waste land, fallow land shows decrease in percentage change. It clearly shows that fallow land, land under nonagricultural use should be used properly to improve land utilization pattern of the state. In present study a comparison is done to analyze percentage change in area under Land utilization pattern for two different periods and growth rates were identified for the same period.

To study changes in land utilization pattern in Parbhani district.

\section{Materials and Methods}

In the present study, Linear Growth Rate (LGR) and Compound Growth Rate (CGR) were estimated for each period to study the growth LUP. For studying the growth rate in land utilization pattern, linear growth rate was estimated by using following linear functions.

$Y=a+b x+e$

Where

$\mathrm{Y}=$ Dependent variable for which growth rate is estimated

$\mathrm{a}=$ Intercept/Constant

$\mathrm{b}=$ Regression/trend coefficient

$\mathrm{x}=$ Period in years

$\mathrm{e}=$ Error term with zero mean and constant variance.

Compound Growth Rate was then estimated by using the following equation:

$\mathrm{Y}=\mathrm{a} \cdot \mathrm{b}^{\mathrm{x}}$

$\mathrm{Y}=$ Dependent variable for which growth rate is estimated

$\mathrm{a}=$ Intercept or constant

$\mathrm{b}=$ Trend / Regression coefficient

$\mathrm{x}=$ Period in years

$\mathrm{b}=(1+\mathrm{r})$

where, $r=$ is compound growth rate

C.G.R. $=($ antilog of b-1) $\times 100$

The necessary data for the selected cereals crops was purely based on secondary sources and it was collected from various issues of Statistical Hand Book of Maharashtra, Season and Crop report of Maharashtra. To work out triennium averages for base period i.e., 200203 , period considered were 2000-01, 20012002, 2002-03 and for end period i.e., 201617 , period for triennium considered were 201415, 2015-16, 2016-17 simple arithmetic averages, percentages of selected parameters of development were used for the comparison of situation in Parbhani over three period of time. Time period I, II and III represents time series data for 2002-03 to 2008-09, 2010-11 to 
2016-17 and 2002-03 to 2016-17 respectively. The present study examines the growth performance of Land Utilization Pattern in Maharashtra State.

Table 1 reports the Land utilization pattern for the period of 2002-03 to 2016-17. It reveals that area under current fallow is constantly decreasing throughout the period and area sown more than once is decreasing. Gross cropped area of the state is also increasing. Area under forest is decreasing but change is minute when compared to other particulars.

\section{Results and Discussion}

\section{Land utilization pattern in Parbhani district of Maharashtra (2002-03 to 2016- 17)}

Land under non-agricultural use is increasing eminently for the entire study period. There is prominent decrease in area sown more than once. Area under permanent pasture is decreasing, but in meager level for every year, when compared to other changes. Forest area of the district also started to diminish.

Due to change in climate, unavailability of water, labour and resources area under agriculture is decreased. Gross cropped area of the district is increased from 81.71 per cent to 88.13 per cent of the total geographical area. Likewise net sown area also increases from 54.77 per cent to 72.58 per cent of total geographical area. Land utilization pattern of the district for the study period is given in Table 1.

\section{Percentage change of land utilization pattern for the period 2002-03 to 2016-17}

Due to availability of resources at needed time net sown area of the district has increase and its percentage change is increase with positive growth. Similarly area under permanent pastures, area sown more than once and cultivable waste shown change in percentage with negative growth. This leads to positive change in land under nonagricultural use, gross cropped area. Land under misc trees, grooves not included in area sown, fallow land shown change in percentage of negative growth of the district is given in table 2 .

\section{Growth rates}

The linear and compound growth rate of the parameters were worked out and presented in Table 3. The average area under forest and barren, uncultivable land were non-significant for entire working period. Area under land under non-agricultural use was significant at 5 $\%$ for period I and II. The average area under current fallow had been significant at $1 \%$ for overall period.

The gross cropped area for period II was significant at 5\%. The average area under cultivable waste land, permanent pastures, land under misc trees, grooves not included in area sown, area sown more than once were non-significant for overall period.

Gross cropped area for state has been increased significantly in both linear and compound growth rate. It had been decreased from 0.04 to 0.61 per cent in linear growth and 0.083 to 0.52 per cent in compound growth rate.

In conclusion, the dynamics of land use pattern in the district over the last fifteen years reveals that there was a significant decline in the area under cultivable wastes and barren land, net sown area, area sown more than once, permanent pastures while there was a sharp increase in land under nonagricultural use, gross cropped area, 
Table.1 Land utilization pattern in Parbhani district of Maharashtra (2002-03 to 2016-17) (Area in ha)

\begin{tabular}{|c|c|c|c|c|c|c|c|c|c|c|c|}
\hline Year & Forest & $\begin{array}{c}\text { Barren and } \\
\text { uncultivabl } \\
\text { e land }\end{array}$ & $\begin{array}{l}\text { Land under } \\
\text { non- } \\
\text { agricultural } \\
\text { use }\end{array}$ & $\begin{array}{c}\text { Cultivabl } \\
\text { e waste } \\
\text { land }\end{array}$ & $\begin{array}{c}\text { Permanent } \\
\text { pastures }\end{array}$ & $\begin{array}{l}\text { Land under } \\
\text { misc trees, } \\
\text { grooves not } \\
\text { included in } \\
\text { net area } \\
\text { sown }\end{array}$ & $\begin{array}{c}\text { Current } \\
\text { fallow }\end{array}$ & $\begin{array}{l}\text { Other } \\
\text { fallow }\end{array}$ & $\begin{array}{c}\text { Net sown } \\
\text { area }\end{array}$ & $\begin{array}{l}\text { Area } \\
\text { sown } \\
\text { more } \\
\text { than } \\
\text { once }\end{array}$ & $\begin{array}{c}\text { Gross } \\
\text { cropped } \\
\text { area }\end{array}$ \\
\hline 2002 & 18000 & 11000 & 27800 & 30000 & 35000 & 12300 & 9700 & 45000 & 345600 & 170000 & 515600 \\
\hline 2003 & 18000 & 9500 & 29100 & 32500 & 28000 & 12500 & 11000 & 44000 & 345200 & 190000 & 535200 \\
\hline 2004 & 17700 & 8500 & 29100 & 20000 & 25000 & 17800 & 10100 & 39800 & 337100 & 465000 & 802100 \\
\hline 2005 & 17700 & 18000 & 30200 & 37000 & 23000 & 16200 & 10000 & 38600 & 296300 & 398200 & 694500 \\
\hline 2006 & 16000 & 12000 & 31100 & 25000 & 19000 & 14200 & 13000 & 37700 & 286300 & 365200 & 651500 \\
\hline 2007 & 15600 & 10000 & 32000 & 32000 & 17500 & 11800 & 15000 & 36900 & 275600 & 356400 & 632000 \\
\hline 2008 & 14000 & 10000 & 36000 & 21000 & 30000 & 11700 & 9700 & 34300 & 540600 & 451000 & 991600 \\
\hline 2009 & 14000 & 19000 & 42000 & 36000 & 21000 & 5000 & 9300 & 24000 & 889000 & 290000 & 1179000 \\
\hline 2010 & 13500 & 10000 & 32000 & 36000 & 21000 & 5000 & 8000 & 30000 & 486000 & 260000 & 746000 \\
\hline 2011 & 12700 & 9000 & 30000 & 36000 & 21000 & 5000 & 7000 & 29000 & 460000 & 250000 & 710000 \\
\hline 2012 & 12500 & 10000 & 32000 & 36000 & 21000 & 2000 & 8000 & 30000 & 815000 & 546000 & 1361000 \\
\hline 2013 & 11000 & 9000 & 32000 & 4000 & 18000 & 4000 & 8000 & 30000 & 483000 & 861000 & 1347000 \\
\hline 2014 & 10000 & 10000 & 32000 & 8000 & 18000 & 10000 & 8000 & 30000 & 517000 & 371000 & 881000 \\
\hline 2015 & 10000 & 10000 & 32000 & 24000 & 30000 & 10000 & 8000 & 30000 & 517000 & 167000 & 684000 \\
\hline 2016 & 10800 & 10000 & 32000 & 24000 & 30000 & 10000 & 6000 & 30000 & 410000 & 155000 & 565000 \\
\hline
\end{tabular}

Source: Department of Statistics, Parbhani (2016) 
Table.2 Percentage change in land utilization pattern of the district

\begin{tabular}{|c|l|c|c|c|c|c|}
\hline $\begin{array}{l}\text { Sr. } \\
\text { No }\end{array}$ & \multicolumn{1}{|c|}{ Category of Land } & $\begin{array}{c}\text { Triennium } \\
\text { ending average } \\
\mathbf{2 0 0 2 - 0 3}\end{array}$ & $\begin{array}{c}\text { Percentage } \\
\text { to total } \\
\text { area }\end{array}$ & $\begin{array}{c}\text { Triennium } \\
\text { ending } \\
\text { average } \\
\mathbf{2 0 0 9 - 1 0}\end{array}$ & $\begin{array}{c}\text { Percentage } \\
\text { to total } \\
\text { area }\end{array}$ & $\begin{array}{c}\text { Percentage } \\
\text { change }\end{array}$ \\
\hline $\mathbf{1}$ & Forest & 18000.00 & 2.85 & 10800.00 & 1.71 & -40 \\
\hline $\mathbf{2}$ & Barren and uncultivable land & 11000.00 & 1.74 & 10000.00 & 1.58 & -9.09 \\
\hline $\mathbf{3}$ & Land under non-agricultural & 35000.00 & 5.54 & 32000.00 & 5.07 & 15.10 \\
\hline & use & 30000.00 & 4.75 & 24000.00 & 3.80 & -20.00 \\
\hline $\mathbf{4}$ & Cultivable waste land & 35000.00 & 4.59 & 30000.00 & 4.75 & -14.28 \\
\hline $\mathbf{5}$ & Permanent pastures & 12300.00 & 0.95 & 10000.00 & 1.58 & -19.16 \\
\hline $\mathbf{6}$ & Land under misc trees, grooves & & & & & \\
\hline & not included in area sown & 9700.00 & 0.79 & 6000 & 0.95 & -38.00 \\
\hline $\mathbf{7}$ & Current fallow & 45000.00 & 2.06 & 30000 & 4.75 & -33.11 \\
\hline $\mathbf{8}$ & Other fallow & 345600.00 & 54.77 & 410000.00 & 72.58 & 18.63 \\
\hline $\mathbf{9}$ & Net sown area & 170000.00 & 26.78 & 155000 & 24.18 & -8.82 \\
\hline $\mathbf{1 0}$ & Area sown more than once & 515600 & 81.71 & 565000.00 & 88.13 & 9.58 \\
\hline $\mathbf{1 1}$ & Gross cropped area & 631000.00 & 100 & 631000.00 & 100 & 0.00 \\
\hline $\mathbf{1 2}$ & Total area & & & & \\
\hline
\end{tabular}

Table.3 Growth rate of land utilization pattern

\begin{tabular}{|c|l|c|c|c|c|c|c|}
\hline Sr. No. & \multicolumn{1}{|c|}{ Particulars } & \multicolumn{3}{|c|}{ LGR } & \multicolumn{3}{c|}{ CGR } \\
\cline { 3 - 8 } & & I & II & III & I & II & III \\
\hline $\mathbf{1}$ & Forest & $-0.12^{* *}$ & $-16.94^{* *}$ & $-6.45^{*}$ & $-0.12^{*}$ & $-18.04^{* *}$ & $-8.24^{* *}$ \\
\hline $\mathbf{2}$ & $\begin{array}{l}\text { Barren and } \\
\text { uncultivable land }\end{array}$ & $1.44^{*}$ & $-6.67^{*}$ & $-1.08^{* *}$ & $1.61^{*}$ & $-4.97^{*}$ & $-0.85^{*}$ \\
\hline $\mathbf{3}$ & $\begin{array}{l}\text { Land under non- } \\
\text { agricultural use }\end{array}$ & $0.00^{*}$ & $-2.30^{*}$ & $-0.62^{*}$ & $-0.27^{*}$ & $-2.01^{*}$ & $-0.56^{*}$ \\
\hline $\mathbf{4}$ & Cultivable waste land & $-2.91^{*}$ & $-12.13^{*}$ & $-3.05^{*}$ & $-3.08^{*}$ & $-12.87^{*}$ & $-5.21^{*}$ \\
\hline $\mathbf{5}$ & Permanent pastures & $3.49^{*}$ & $5.07^{*}$ & $-0.48^{*}$ & $-3.89^{*}$ & $4.45^{*}$ & $-0.59^{*}$ \\
\hline $\mathbf{6}$ & $\begin{array}{l}\text { Land under misc } \\
\text { trees, grooves not }\end{array}$ & $-2.74^{*}$ & $11.18^{*}$ & $2.46^{*}$ & $-2.60^{* *}$ & $8.34^{*}$ & $0.85^{*}$ \\
\hline & & & & & & \\
\hline $\mathbf{7}$ & included in area sown & & & & & & \\
\hline $\mathbf{8}$ & Current fallow & $26.58^{*}$ & $-19.12^{*}$ & $-1.28^{* *}$ & $31.94^{* *}$ & $-13.48^{*}$ & $-2.20^{*}$ \\
\hline $\mathbf{9}$ & Other fallow & $12.50^{*}$ & $1.83^{*}$ & $5.27^{* *}$ & $13.43^{* *}$ & $2.00^{*}$ & $6.13^{* *}$ \\
\hline $\mathbf{1 0}$ & Net sown area & $2.01^{*}$ & $-6.83^{*}$ & $-1.91^{*}$ & $1.46^{* *}$ & $-5.79^{*}$ & $-2.10^{*}$ \\
\hline $\mathbf{1 1}$ & Area sown more than & $7.77^{*}$ & $-1.72^{*}$ & $0.77^{*}$ & $9.55^{*}$ & $-4.37^{*}$ & $-0.55^{*}$ \\
\hline & Once & & & & & & \\
\hline
\end{tabular}

*Significant at 5 per cent, $* *$ Significant at 1 per cent 
The land under misc trees, grooves not included in net area sown. The study reveals that there has been a significant reduction in the area under common lands mainly because of the diversion of these lands for nonagricultural purposes. Stabilization of irrigated acreage is perhaps a more important step than the expansion of irrigation so as to better utilize land resources. The analysis of factors affecting the extent of fallow lands at the farm level using cross-section data reveals that increase in farm size, non-agricultural income and labor shortage have strong positive impact on the extent of fallow lands, while the credit availability and irrigation facilities are found to reduce the extent of fallow lands at the farm level. Another important measure is the institutional reform to ensure the prevention or regulation of converting fertile agricultural lands for nonagricultural purposes is another important mechanism to stabilize the net sown area. Conversion for non-agricultural purposes appears to be the most important threat to the common property land resources such as cultivable wastelands, land under miscellaneous tree crops and groves and grazing lands.

\section{References}

Sinha, D.K., Singh, K.M., Nasim Ahmad (2017), "An Investigation of Factors for Changing Land Use Pattern in Bihar with a Piercing Insight on Current Fallow Lands". MPRA Paper No. 80264, (22).

Rejula. K., and Rashmi Singh, (2015), “An analysis of changing land use pattern and cropping pattern in a scenario of increasing food insecurity in Kerala state", Economic Affairs, 60(1): 123129.

Jitendra, K.J., and Narender Verma (2013)," The Study of the Land Use/Land Cover in Varanasi District Using Remote Sensing and GIS", Transaction Institution of Indian Geographers, 35(2): 202-212.

Arunachalam, S., K. Maharani, S. Chidambaram, M.V. Prasanna, M. Manivel and C. Thivya (2011), "A study on the land use pattern change along the coastal region of Nagapattinam, Tamil Nadu". International Journal of Geometrics and Geosciences, 1(4): 720.

\section{How to cite this article:}

Awchar, A.A., K.V. Deshmukh and Shelke, R.D. 2019. Growth Action of Land Utilization Pattern in Parbhani District of Maharashtra. Int.J.Curr.Microbiol.App.Sci. 8(05): 1839-1844. doi: https://doi.org/10.20546/ijcmas.2019.805.214 